\title{
CEREAL BREEDING FOR ORGANIC FARMING: CROP TRAITS RELATED WITH COMPETITIVENESS AGAINST WEEDS
}

\author{
Dace Piliksere*, Vija Strazdina***, Zaiga Vīcupe**, Zaiga Jansone**, Linda Legzdina*, \\ Indra Beinaroviča*, and Arta Kronberga* \\ * State Priekuḷi Plant Breeding Institute, Zinātnes iela 2, Priekuḷi LV-4126, LATVIA; \\ dacepil@gmail.com \\ ** State Stende Cereals Breeding Institute, "Dižzemes", Dižstende, Lībagi parish, Talsi County, LV-3258, LATVIA; \\ stende.selekcija@apollo.Iv
}

Communicated by Zinta Gaile

\begin{abstract}
The objectives of the investigation were to identify competitive traits in cereal species in order to contribute to development of a methodology for evaluation of cereal genotypes for their competitive capacity against weeds, which is important for organic breeding aims. The investigation was carried out with spring barley, spring oat, winter triticale and winter wheat genotypes in organic crop rotations in two different locations. Relations between crop traits and weed dry weight were evaluated by Pearson correlation coefficients. The results stressed the significance of some crop traits for cereal competitiveness against weeds for organic breeding purposes: (i) growth habit, canopy height, and crop development rate for spring barley; (ii) crop development rate for spring oats; (iii) winter hardiness and the coefficient of tillering for winter triticale, and (iv) winterhardiness, the coefficient of tillering, the number of productive stems, crop canopy and plant height for winter wheat. It coud be useful to include measurements of crop ground cover for estimating competitiveness of cereal species against weeds.
\end{abstract}

Key words: cereals, organic breeding, crop traits, competitiveness against weeds.

Cereal growth and yield can be significantly reduced by competition with weeds for nutrients, water and light (Zimdahl, 2004). Weed management is one of most important agricultural problems, particularly in organic growing systems where chemical pesticides are forbidden, and therefore, alternative weed management strategies are searched for. An integrated weed management system can include selection of crop varieties that can suppress or withstand weed competition. Selection of crop varieties that are suitable for growing conditions and are competitive can reduce additional costs that would be necessary for weed management (Bastiaans et al., 2008). Compared with conventional agriculture, in organic agriculture the effects of cultural practices (e.g. fertilisation and direct weed control) on crop-weed interactions usually manifest themselves more slowly. It follows that weed management should be tackled in an extended time domain and needs deep integration with other cultural practices, aiming to optimise the whole cropping system rather than weed control per se (Barberi, 2002). By crop breeding, which is an important element of the cropping system, it is possible to select cereal genotypes with improved competitiveness against weeds.

Assessing weed suppression ability of crops has become more important with the development of organic plant breeding. Selection of cereal varieties suited to organic agriculture requires a different approach to that used for selection in conventional high input systems. This is because there is less potential for crops to compensate for limitations to yield imposed by diseases, weeds or low nutrients, as well as need to adapt to highly variable environmental conditions in organic agriculture (Wolfe et al., 2008). Improvement of weed suppression ability (new ideotype of a plant) is stressed as one of the main objectives in the breeding programmes for small grain cultivars for organic farming. As organic conditions are less controllable and more variable, breeding should be aimed on creation of better adapted varieties to organic soil fertility, with improved yield stability and product quality, as well as with higher ability to withstand the weeds, pests and diseases. Therefore, the traits required for the varieties in organic and conventional farming differ (Lammerts van Bueren, 2002). Determination of the most important traits for the selection criteria in plant breeding for organic farming is one of the first tasks for developing of local breeding programmes (Kronberga, 2008). Christensen (1995) suggested that it seems conceivable to include the selection for high competitive ability in cereal breeding programmes, as the results of his research showed virtually no correlation between yielding ability and weed suppression ability.

Although crop competitiveness against weeds is determined both by the root system, and shoot growth and development, testing of new varieties is based mainly on crop aboveground part characteristics (Wilson, 1988). Many of the physiological traits for desirable belowground criteria are less well understood and difficult to evaluate, as well as very little is known 
about genotypic variation among varieties. Therefore, crop root characteristics are less practical for use by plant breeders in their selections (Wolfe et al., 2008). Cultivars of even one crop species can differ by their development - morphological and phenological traits. These different characteristics determine the competitive ability of crop cultivars against weeds. Traits that give an advantage in competition can appear and be demonstrated only when species are growing together. Some varieties have higher weed suppression than others, although this cannot be attributed to one single characteristic. Rather, it is an interaction among several desirable traits that results in competitive ability against weeds, and varieties may compensate for weakness in one component with strength in others (Kruepl et al., 2007). As crop traits with value in cereal competitive ability against weeds are: high ground cover and good shading ability (rapid early growth rate, high tillering ability, planophile leaf habit, increasing plant height etc.) (Hoad et al., 2006; Wolfe et $a l ., 2008)$. For winter cereals, the most important traits are lush autumn growing and over-wintering (Liatukas et al., 2008).

The present study was designed with the aim to identify competitive traits in cereal species, to contribute to development of a methodology for estimation of cereal genotypes for their competitive capacity against weeds, which is important for organic breeding aims.

The investigation was carried out at the State Priekuli Plant Breeding Institute and at the State Stende Cereals Breeding Institute in Latvia in 2009-2012. Field experiments were arranged in organic crop rotations on sod-podzolic loamy sand soils, in Priekuli (Table 1) and in Stende (Table 2), with two cereal species at each location - spring barley (varieties 'Abava', 'Anabell', 'Anni', 'Dziugiai', 'Idumeja', 'Inari', 'Primus', 'Rasa', 'Rubiola', 'Vienna' and ten breeding lines) and winter triticale (variety 'Dinaro' and 20 breeding lines) in Priekulii; spring oats (variety 'Laima' and 20 breeding lines) and winter wheat (varieties 'Ada', 'Bussard', 'Fredis', 'Krista', 'Leiffer', 'Olivin', 'Skagen', 'Skalmeje', 'SW Maxi', 'Zentos' and ten breeding lines) in Stende. Harrowing was not performed in the trials, to exclude the impact of this factor.

Observations were made and the data were collected during the investigation period. Various crop traits were used to evaluate competitiveness of cereal genotypes: crop plant development rate in terms of days from sowing to phenological phases such as tillering (BBCH 21), stem elongation (BBCH 30), heading/panicle stage (BBCH 50) and fully ripening (BBCH 90); the number of germinated plants and the number of productive stems; visual evaluation of overwintering for winter cereals (using the scale: 1 - all plants alive; 9 - more than $80 \%$ dead); growth habit at tillering (BBCH 25-29) and at stem elongation (BBCH 39$)$ evaluated visually (using the scale: 1 - erectophile; 9 - planophile); canopy height at the beginning and at the end of stem elongation (BBCH 31-32 and $\mathrm{BBCH} 47-51$, respectively), plant height before harvesting (BBCH 90-92), and length and width of flag leaves (BBCH 47-51). Crop ground cover was assessed visually in as a percentage several times from the end of crop tillering to fully ripening. Correlations of cereal plant traits with weed dry weight (total, annual, perennial) was calculated. Weed samples were collected at anthesis of cereal cops, dried and weighed.
Table 1

CHARACTERISTICS OF GROWING CONDITIONS IN TRIAL LOCATIONS IN PRIEKUḶI IN 2010-2012

\begin{tabular}{c|c|c|c|c|c|c}
\hline \multicolumn{1}{c|}{ Year } & \multicolumn{2}{|c|}{2010} & \multicolumn{2}{c|}{2011} & \multicolumn{2}{c}{2012} \\
\hline \multicolumn{1}{c}{ Crop } & $\begin{array}{c}\text { spring } \\
\text { barley }\end{array}$ & $\begin{array}{c}\text { winter } \\
\text { triticale }\end{array}$ & $\begin{array}{c}\text { spring } \\
\text { barley }\end{array}$ & $\begin{array}{c}\text { winter } \\
\text { triticale }\end{array}$ & $\begin{array}{c}\text { spring } \\
\text { barley }\end{array}$ & $\begin{array}{c}\text { winter } \\
\text { triticale }\end{array}$ \\
\hline Sowing date & 21.04 & 10.10 .09 & 20.04 & 23.09 .10 & 28.04 & 19.09 .11 \\
\hline $\begin{array}{l}\text { Soil } \\
\text { characteristics: }\end{array}$ & & & & & & \\
$\mathrm{H}_{\mathrm{KCl}}$ & 5.7 & 5.0 & 5.4 & 6.0 & 5.7 & 5.8 \\
${\text { humus, } \mathrm{g} \mathrm{kg}^{-1}}^{28}$ & 25 & 21 & 21 & 23 & 23 \\
$\mathrm{P}_{2} \mathrm{O}_{5}, \mathrm{mg} \mathrm{kg}^{-1}$ & 111 & 56 & 116 & 205 & 160 & 128 \\
$\mathrm{~K}_{2} \mathrm{O}, \mathrm{mg} \mathrm{kg}^{-1}$ & 144 & 74 & 98 & 150 & 93 & 135 \\
Pre-crop & $\begin{array}{c}\text { peas - } \\
\text { green } \\
\text { manure }\end{array}$ & & $\begin{array}{c}\text { clover } \\
\text { peas - } \\
\text { green } \\
\text { manure }\end{array}$ & \multicolumn{3}{c}{$\begin{array}{c}\text { clover } \\
\text { peas - } \\
\text { manure }\end{array}$} \\
clover \\
\end{tabular}

Table 2

CHARACTERISTICS OF GROWING CONDITIONS IN TRIAL LOCATIONS IN STENDE IN 2010-2012

\begin{tabular}{c|c|c|c|c|c|c}
\hline Year & \multicolumn{2}{|c|}{2010} & \multicolumn{2}{c|}{2011} & \multicolumn{2}{c}{2012} \\
\hline Crop & $\begin{array}{c}\text { spring } \\
\text { oats }\end{array}$ & $\begin{array}{c}\text { winter } \\
\text { wheat }\end{array}$ & $\begin{array}{c}\text { spring } \\
\text { oats }\end{array}$ & $\begin{array}{c}\text { winter } \\
\text { wheat }\end{array}$ & $\begin{array}{c}\text { spring } \\
\text { oats }\end{array}$ & $\begin{array}{c}\text { winter } \\
\text { wheat }\end{array}$ \\
\hline Sowing date & 21.04 & 15.09 .09 & 23.04 & 14.09 .10 & 27.04 & 19.09 .11 \\
\hline
\end{tabular}

Soil

characteristics:

\begin{tabular}{|c|c|c|c|c|c|c|}
\hline $\mathrm{pH}_{\mathrm{KCl}}$ & 6.0 & 6.3 & 5.6 & 6.4 & 6.4 & 6.2 \\
\hline humus, $\mathrm{g} \mathrm{kg}^{-1}$ & 23 & 30 & 17 & 21 & 21 & 21 \\
\hline $\mathrm{P}_{2} \mathrm{O}_{5}, \mathrm{mg} \mathrm{kg}^{-1}$ & 165 & 167 & 118 & 172 & 207 & 262 \\
\hline $\mathrm{K}_{2} \mathrm{O}, \mathrm{mg} \mathrm{kg}^{-1}$ & 127 & 114 & 121 & 161 & 130 & 148 \\
\hline re-crop & $\begin{array}{l}\text { spring } \\
\text { wheat }\end{array}$ & peas & $\begin{array}{l}\text { spring } \\
\text { wheat }\end{array}$ & clover & $\begin{array}{l}\text { spring } \\
\text { wheat }\end{array}$ & clover \\
\hline
\end{tabular}

The bivariate correlation method (IBM SPSS Statistics 19) was applied to calculate Pearson correlation coefficients for relations between different crop traits and weed dry weight at the probability levels 0.05 and 0.01 .

The results of the three-year investigation period several relationships between crop traits and total, annual or perennial weed dry weights.

Spring barley. Plant density after germination correlated negatively with total and annual weed dry weights in 2011 and 2012 (Table 3). Slower crop development till tillering resulted in a lower dry weight of perennial weeds in 2011. More erectophile crop growth habit at BBCH 25-29 appeared to lower total and annual weed dry weights in 2012. Crop growth rate till stem elongation showed no significant correlations with weed dry weights in any of the years. Crop canopy height correlated negatively with dry weights of total and annual weeds in all of the years. More erectophile crop growth habit at $\mathrm{BBCH} 39$ resulted in lower dry weights of total and annual weeds in 2011 and 2012. Longer flag leaf appeared to correlate positively with total and annual weed dry weights in 2012. The width of flag leaf had no significant relations with weed dry weights in any of the years. Slower crop development till heading resulted in higher total and annual weed dry weights in 2011 and 2012. Slower crop development till fully ripening correlated positively with weed dry weights in 2012. Higher crop plant height at $\mathrm{BBCH}$ 92 was negatively related with a total weed dry weight in 2010. Higher number of productive stems resulted in a higher total 
SIGNIFICANT CORRELATIONS OF SPRING BARLEY TRAITS WITH WEED DRY WEIGHTS

\begin{tabular}{|c|c|c|c|c|c|c|c|}
\hline \multirow[t]{2}{*}{ Traits } & \multicolumn{3}{|c|}{ Total weeds } & \multicolumn{2}{|c|}{ Annual weeds } & \multicolumn{2}{|c|}{ Perennial weeds } \\
\hline & 2010 & 2011 & 2012 & 2011 & 2012 & 2011 & 2012 \\
\hline Plant density after germination & & $-0.349 * *$ & $-0.328 * *$ & $-0.375 * *$ & $-0.331 * *$ & & \\
\hline Sowing-tillering, days & & & & & & $-0.349 * *$ & \\
\hline Growth habit (BBCH 25-29) & & & $0.239^{*}$ & & $0.295^{*}$ & & \\
\hline Canopy height (BBCH 31-32) & $-0.513 * *$ & $-0.306^{*}$ & $-0.280 *$ & $-0.340 * *$ & $-0.281 *$ & & \\
\hline Growth habit (BBCH 39) & & $0.271^{*}$ & $0.405 * *$ & $0.310^{*}$ & $0.406^{* *}$ & & \\
\hline Canopy height (BBCH 47-51) & $-0.536^{* *}$ & & $-0.364 * *$ & $-0.268^{*}$ & $-0.364 * *$ & & \\
\hline Sowing-heading, days & & $0.443 * *$ & $0.425 * *$ & $0.500 * *$ & $0.424 * *$ & & \\
\hline Number of productive stems & $0.308^{*}$ & & & & & & \\
\hline Plant height (BBCH 90-92) & $-0.458 * *$ & & & & & & \\
\hline Sowing-maturity, days & & & $0.386 * *$ & & $0.382 * *$ & & $0.270^{*}$ \\
\hline Coefficient of tillering & $0.363^{*}$ & $0.354 * *$ & & $0.390 * *$ & & & \\
\hline
\end{tabular}

*, ** significant at the 0.05 and 0.01 probability level, respectively

weed dry weight in 2010. Higher coefficient of tillering showed positive correlation with a total weed dry weight in 2010 and 2011 and with an annual weed dry weight in 2011. Higher crop ground covers resulted in significantly lower weed dry weight in many cases.

Spring oats. Plant density after germination had no significant correlation with weed dry weight in any of the years. A slower crop development rate till tillering resulted in lower total and perennial weed dry weight in $2012\left(\mathrm{r}=0.304^{* *}\right.$ and $\mathrm{r}=0.297^{*}$, respectively), but the correlation was not significant in 2010 and 2011. Crop growth habit neither at BBCH 25-29, nor at BBCH 39 had significant correlation with weed dry weights in any of the years. Slower crop development rate till stem elongation resulted in lower annual weed dry weight in 2010 ( $\mathrm{r}=$ $\left.-0.243^{*}\right)$, but in higher weed dry weight in $2012\left(\mathrm{r}=0.308^{* *}, \mathrm{r}\right.$ $=0.273^{*}, \mathrm{r}=0.271^{*}$ for total, annual and perennial weeds, respectively); no significant relation was observed in 2011. Higher crop canopy at $\mathrm{BBCH} 31-32$ correlated negatively with annual weed dry weight in $2011\left(\mathrm{r}=-0.345^{* *}\right)$, while the correlation was not significant in 2010 and 2012. Longer flag leaf correlated positively with an annual weed dry weight in 2010 (r $\left.=0.266^{*}\right)$, but there were no significant relations in 2011 and 2012. The width of flag leaf did not correlate significantly with weed dry weight in any of the years. Crop development rate till panicle stage, as well as till fully ripening had no significant relation with weed dry weight. Also, crop plant height at $\mathrm{BBCH}$ 92 and the number of productive stems did not correlate significantly with weed dry weight. Higher coefficient of tillering showed a negative correlation with annual weed dry weight in 2010 ( $r=-0.243 *$, while no significant relations were observed in 2011 and 2012. Higher crop ground cover resulted in signicantly lower weed dry weight in many cases.

Winter triticale. A negative correlation between winterhardiness of triticale and total, as well as annual weed dry weights was observed in 2011 (Table 4). Crop growth habit at BBCH 25-29, as well as crop development rate till stem elongation had no significant relation with weed dry weights. However, slower crop plant development till fully ripening resulted in a higher annual weed dry weight in 2012. Higher crop canopy height at $\mathrm{BBCH} 31-32$ correlated positively with a perennial weed dry weight in 2010, but negatively with an annual weed dry weight in 2011. A similar positive correlation with a perennial weed dry weight was observed also for crop canopy height at BBCH 47-51 in 2010. A length and a width of flag leaf appeared to have a significant correlation with weed dry weights in 2011. Higher crop plant at BBCH 92 had a positive correlation with a perennial weed dry weight in 2010. The number of crop productive stems had an opposite correlations with a total weed dry weight in 2011 and 2012. Higher number of productive stems correlated negatively with an annual weed dry weight in 2011. Higher coefficient of tillering had a negative relation with total and annual weed dry weights in 2011. Higher crop ground covers resulted in significantly lower weed dry weight in many cases.

Winter wheat. Better winterhardiness of wheat resulted in lower weed dry weights in 2012 (Table 5). Crop growth habit at BBCH 25-29, as well as crop development rate till stem elongation had no significant correlations with weed dry weights. Higher crop canopy height correlated negatively with weed dry weights in 2012. More erectophile crop growth habit at BBCH 39 resulted in lower total and perennial weed dry weights in 2012. More crop plants with inclinated flag leaves correlated negatively with a perennial weed dry weight in 2010. Longer flag leaf appeared to correlate positively with a perennial weed dry weight in 2011. Wider flag leaf had a positive correlation with a total weed dry weight in 2010 and with a perennial weed dry weight in 2011. Crop development rate till heading, as well as till fully ripening growth stages had no significant correlations with weed dry weights. Higher crop plant at $\mathrm{BBCH} 92$ correlated negatively with weed dry weights in 2012. Higher number of productive stems and higher coefficient of tillering resulted in lower dry weights in 2011 and 2012. Higher crop ground covers resulted in significantly lower weed dry weight in many cases.

Cereals suppress weed growth; however, diverse cereal genotypes have different competitiveness against weeds, depending on crop growth and aboveground characteristics. Several authors (Kruepl et al., 2007; Wolfe et al., 2008) have found that competitive ability is usually not attributed to a single characteristic, either within or between varieties, but the interaction among a series of desirable characteristics is important. Leistrumaite et al. (2009) found that the ability of oats to cover soil at 
SIGNIFICANT CORRELATIONS OF WINTER TRITICALE TRAITS WITH WEED DRY WEIGHTS

\begin{tabular}{|c|c|c|c|c|c|}
\hline \multirow[t]{2}{*}{ Traits } & \multicolumn{2}{|c|}{ Total weeds } & \multicolumn{2}{|c|}{ Annual weeds } & \multirow{2}{*}{$\frac{\text { Perennial weeds }}{2010}$} \\
\hline & 2011 & 2012 & 2011 & 2012 & \\
\hline Winterhardiness & $-0.583 * *$ & & $-0.585^{* *}$ & & \\
\hline Canopy height (BBCH 31-32) & & & $-0.261^{*}$ & & $0.542 *$ \\
\hline Flag leaf length & $0.275^{*}$ & & $0.286^{*}$ & & \\
\hline Flag leaf width & $0.337 * *$ & & $0.312 *$ & & \\
\hline Canopy height (BBCH 47-51) & & & & & $0.498^{*}$ \\
\hline Plant height (BBCH 90-92) & & & & & $0.461^{*}$ \\
\hline Sowing-maturity, days & & & & $0.250^{*}$ & \\
\hline Coefficient of tillering & $-0.261 *$ & & $-0.278^{*}$ & & \\
\hline
\end{tabular}

$\overline{*, * * \text { significant }}$ at the 0.05 and 0.01 probability level, respectively

Table 5

SIGNIFICANT CORRELATIONS OF WINTER WHEAT TRAITS WITH WEED DRY WEIGHTS

\begin{tabular}{|c|c|c|c|c|c|c|c|}
\hline \multirow[t]{2}{*}{ Traits } & \multicolumn{3}{|c|}{ Total weeds } & \multicolumn{2}{|c|}{ Annual weeds } & \multicolumn{2}{|c|}{ Perennial weeds } \\
\hline & 2010 & 2011 & 2012 & 2011 & 2012 & 2011 & 2012 \\
\hline Winterhardiness & & & $-0.587 * *$ & & $-0.508 * *$ & & $-0.462 * *$ \\
\hline Growth habit (BBCH 25-29) & & & & & & $0.462 * *$ & \\
\hline Canopy height (BBCH 31-32) & & & $-0.416^{* *}$ & & $-0.362^{* *}$ & & $-0.362 *$ \\
\hline Growth habit (BBCH 39) & & & $0.426^{* *}$ & & & & $0.396 * *$ \\
\hline Flag leaf length & & & & & & $0.296^{*}$ & \\
\hline Flag leaf width & $0.277 *$ & & & & & $0.294 *$ & \\
\hline Canopy height (BBCH 47-51) & & & $-0.297 *$ & & $-0.324 *$ & & \\
\hline Number of productive stems & & $-0.513 * *$ & $-0.659 * *$ & $-0.509 * *$ & $-0.525 * *$ & $-0.407 * *$ & $-0.539 * *$ \\
\hline Plant height (BBCH 90-92) & & & $-0.441 * *$ & & $-0.341 * *$ & & $-0.366^{* *}$ \\
\hline Coefficient of tillering & & $-0.512^{* *}$ & $-0.633 * *$ & $-0.501 * *$ & $-0.459 * *$ & $-0.445^{* *}$ & $-0.539 * *$ \\
\hline
\end{tabular}

*,** significant at the 0.05 and 0.01 probability level, respectively

stem elongation stage strongly correlated with yield, and they concluded that it is possible to select oat breeding lines for organic growing at early growth stages without detailed screening of canopy traits during the entire vegetation season, as yield showed considerable but weaker correlation with the number of productive tillers. However, for barley, soil cover only weakly correlated with the number of productive tillers and plant height, which complicates selection of adequate lines possessing high soil cover abilities. Following these suggestions, it would be a perspective direction to improve the results of the present study by adding some new crop traits or merging the current different crop traits to obtain stronger correlation with weed dry weight. Some research has already been done to evaluate spring barley competitiveness against weeds in Latvia in previous years (Maliecka, 2003; Kokare and Legzdina, 2010). The results of our study agreed to that of Kokare and Legzdina (2010), but it must be noted that our research covered more cereal species.

For winter triticale, only the results for the years 2011 and 2012 were suitable for interpretation, as there were less observations $(\mathrm{N}=22)$ between each pair of traits, as well as very bad winter hardiness, following by lack of appearance of characteristics of triticale genotypes, in 2010. Probably, some results were opposite between both years of the investigation. Liatukas et al. (2008) suggested that autumn growth and over-wintering can be considered as two main traits that affect later crop stand development. In their study, autumn growth type was strongly corre- lated with spring re-growth and soil covering at the stem elongation stage for winter wheat. Considering the correlation obtained, autumn growth type can be one of traits for the selection of genotypes with higher resistance to weeds. Overwintering was one of essential traits for winter cereals under the organic growing system. Correlation analysis showed that this trait strongly affected spring re-growth intensity and later soil covering. A positive and significant correlation between winter triticale yield and winter hardiness was observed by Kronberga (2008). Genotypes with better winter hardiness had a larger amount of ears per $1 \mathrm{~m}^{2}$ and as result - better weed competitiveness and a higher yield. However, the obtained results did not prove the necessity to select for organic farming triticale genotypes with long stems, because there was no significant correlation between yield and plant height. Also, the influence of growth habit on weed competitiveness was nor detected. Kronberga (2008) concluded that triticale genotypes with different plant heights, growth habits, leaf size would be suitable for organic growing conditions.

In our investigation, the results of crop aboveground traits correlated only slightly with weed ground cover; therefore, the weed development could be affected by other factors than crop aboveground characteristics included in the investigation. Little is known about crop:weed belowground competition, which could be one of the factors of great impact. Bertholdsson and Jönsson (1994), in investigation with 25 barley and 25 oat varieties, found that relative root growth rate explained more than 
$50 \%$ in weed biomass variation in barley, while shoot biomass differences explained none of the variance. For oats, a similar amount of variation was explained by rates of root and shoot growth.

In conclusion, on the basis of the results of our investigation, we stress the significance of the following crop traits, which are important for estimating cereal competitiveness against weeds for organic breeding purposes: (i) growth habit at $\mathrm{BBCH} 25-29$ and at BBCH 39, canopy height at BBCH 31-32 and at BBCH 47-51, crop development rate in days from sowing till heading and till fully ripening growth stages for spring barley; (ii) crop development rate in days from sowing till tillering and till fully ripening growth stages for spring oats; (iii) winter hardiness and the coefficient of tillering for winter triticale and (iv) winter hardiness, the coefficient of tillering, the number of productive stems, crop canopy height at $\mathrm{BBCH} 31-32$ and at $\mathrm{BBCH}$ 47-51, crop plant height at BBCH 92 for winter wheat. Measuring of crop ground covers also could be useful for estimating competitiveness of cereal species against weeds. The current results could be improved by merging the various crop traits to obtain some coefficients with stronger correlation with weed dry weight. Long-term field experiments would have high importance, to examine the observed correlations, as a great amount of factors playing a role in crop : weed competitive interactions can differ by years.

\section{ACKNOWLEDGEMENTS}

This study was performed with financial support of European Social Fund co-financed project "Development, improvement and implementation of environmentally friendly and sustainable crop breeding technologies" 2009/0218/1DP/1.1.1.2.0/09/APIA/VIAA/099.

\section{REFERENCES}

Bàrberi, P. (2002). Weed management in organic agriculture: Are we addressing the right issues? Weed Res., 42, 177-193.
Bastiaans, L., Paolini, R., Baumann, D. T. (2008). Focus on ecological weed management: What is hindering adoption? Weed Res., 48, 481-491.

Bertholdsson, N.-O., Jönsson, R. (1994). Weed competition in barley and oats. In: Proceedings of 3rd ESA Congress, Abano-Padova, (pp. 656-657).

Christensen, S. (1995). Weed suppression ability of spring barley varieties. Weed Res., 35, 241-247.

Hoad, S. P., Davies, D. H. K., Topp, C. F. E. (2006). How to select varieties for organic farming: Science and practice. Aspects Appl. Biol., 79, $117-120$.

Kokare, A., Legzdina, L. (2010). Traits influencing spring barley competitiveness against weeds under organic and conventional conditions. In: Proceedings of International Scientific Conference: Research for Rural Development 2010, 16, Jelgava (Latvia), 19-21 May 2010 (pp. 11-16).

Kronberga, A. (2008). Selection criteria in triticale breeding for organic farming. Latvian J. Agron., 11, 89-94.

Kruepl, C., Hoad, S., Davies, K., Bertholdsson, N.-O., Paolini, R. (2007). Weed competitiveness. In: Cereal Variety Testing for Organic and Low Input Agriculture. SUSVAR Handbook, W1-W17.

Lammerts van Bueren, E. T. (2002). Organic plant breeding and propagation: Concepts and strategies. PhD Thesis. Wageningen University. The Netherland. 196 pp.

Leistrumaitè, A., Liatukas, Ž., Razbadauskienė, K. (2009). The spring cereals traits of soil cover, disease resistance and yielding essential for organic growing. Agron. Res., 7, 374-380.

Liatukas, Ž., Leistrumaitè, A., Razbadauskienè, K. (2008). The main traits of winter wheat for breeding for organic farming in Lithuania. Latvian $J$. Agron., 11, 113-119.

Mal̦ecka, S. (2003). Competitive ability of barley varieties and weeds in agrophytocenosis. Latvian J. Agron., 5, 151-154.

Wilson, J. B. (1988). Shoot competition and root competition. J. Appl. Ecol., 25, 279-296.

Wolfe, M. S., Baresel, J. P., Desclaux, D., Goldringer, I., Hoad, S., Kovacs, G., Löschenberger, F., Miedaner, T., Østergård, H., Lammerts van Bueren, E. T. (2008). Developments in breeding cereals for organic agriculture. Euphytica, 163, 323-346.

Zimdahl, R. L. (2004). Weed-crop Competition: A Review. 2nd ed. Blackwell Publishing. 220 pp.

\section{GRAUDAUGU SELEKCIJA BIOLOĢISKAJAI LAUKSAIMNIECĪBAI: KONKURĒTSPĒJĀ AR NEZĀLĒM NOZĪMĪGAS GRAUDAUGU PAZİMES}

Pētījuma uzdevums bija identificēt graudaugu pazīmes, kas nosaka konkurētspēju ar nezālēm, lai pilnveidotu graudaugu genotipu novērtēšanas paṇēmienus bioloǵiskās selekcijas mērḳiem. Izmēǵinājumi tika ierīkoti ar vasaras miežu, vasaras auzu, ziemas tritikāles un kviešu genotipiem biolog̣iskajās augsekās Priekuḷos un Stendē. Izmantojot Pīrsona korelācijas metodi, tika vērtēta dažādu graudaugu virszemes daḷ īpašību saistība ar kopējo, īsmūža un daudzgadīgo nezāḷu sauso masu. Vairākas graudaugu pazīmes būtiski korelēja ar nezāḷu sauso masu: (i) cera forma un augšanas tips, zelmeṇa augstums, labības attīstības temps vasaras miežiem; (ii) labības attīstības temps vasaras auzām; (iii) ziemcietība un cerošanas koeficients ziemas tritikālei un (iv) ziemcietība, cerošanas koeficients un produktīvo stiebru skaits, zelmena augstums un auga garums ziemas kviešiem. Attiecīgo graudaugu sugu konkurētspējas ar nezālēm izvērtēšanai perspektīvi varētu iekḷaut arī labības procentuālo augsnes segumu mērījumus. 